\title{
Madrid quakes as Barcelona shows ambition
}

Xavier Bosch, Barcelona

Madrid's traditional dominance of Spanish science is coming under pressure from the growing aspirations of Barcelona, its great historical rival. And scientists in the Spanish capital are concerned that their Catalonian competitor will beat them in terms of funding for research initiatives.

Madrid's researchers note that, since last spring, two Catalan ministers have been in charge of the Ministry of Science and Technology (MST), which controls the flow of research funds from the Spanish government. The appointments were seen as an attempt by the conservative government to shore up its weak support in Catalonia.

Researchers in Barcelona have long complained about Madrid's dominance of Spanish science. They point out, for example, that during Franco's rule the Higher Council of Scientific Research (CSIC) - the country's largest research agency - built most of its research centres in Madrid.

Despite moves to decentralize Spain after the dictator's death in 1975 - including the establishment of a powerful regional government for Catalonia - research activity remains heavily concentrated in the capital. In 1999, total research spending in

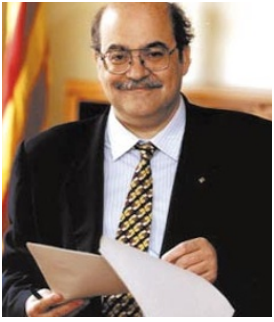

Madrid was Pta 265 billion (US\$1.4 billion), around $1.5 \%$ of the economy, against Pta 188 billion (1.1\% of the economy) in Catalonia.

"There's a serious research deficit in Andreu Mas-Colell wants to distribute Barcelona," says Pere Puigdoménech, who research around Spain. is director of the city's Institute of Molecular Biology. He says two-thirds of CSIC biomedical researchers are located in Madrid. "The government has transferred practically no research powers to Catalonia," he says.

Nevertheless, the Catalan regional government set up a research department last April with an annual budget of Pta 8.5 billion. And Barcelona scientists have established several successful research centres, including the Municipal Institute of Medical Research and the Institute for High Energy Physics.

But some recent developments have put Madrid's scientists on the defensive. For example, the MST has offered Barcelona Pta 5 billion to build a science park, against Pta 2.8 billion for a similar project in Madrid.
Rodolfo Miranda, vice-chancellor of the Autonomous University of Madrid, accepts this distribution in funds. But he is annoyed that Barcelona is also getting a larger share of European Commission funds for building and refurbishing scientific facilities. In the next two years, he notes, Catalonia - mostly Barcelona - will get Pta 12 billion, compared with Pta 4 billion for Madrid, and Pta 5 billion for the Basque Country.

Miranda says this allocation will hurt Madrid because the city has so many more researchers and laboratories than Barcelona. The city has three times as many CSIC centres as Barcelona and twice as many universities.

But Federico Mayor, director of Madrid's Centre for Molecular Biology, says that both cities need to strengthen their scientific bases simultaneously. Jordi Mas, director of the Catalan Foundation for Research, agrees. "A strong Madrid and a weak Barcelona, or vice versa, won't help to position Spain in the future of European science," Mas says.

Andreu Mas-Colell, who runs the Catalan government's research department, says he would like Spain's science map to look like that of Germany, with competitive research distributed between many different cities.

\section{Primate centre promises insight into ape research}

\section{Nina Schnapp, Munich}

A primate research centre with a difference opens this week in Leipzig. All of its work will be undertaken in full view of the public, who will be able to visit it to watch the four species of great ape housed there.

The Wolfgang Köhler Primate Research Centre, built at a cost of DM30 million (US\$13.5 million), is situated in the city's zoo. Its founders hope that the centre's 'open-door' approach will help to boost public confidence in their work.

"The new centre offers us a unique opportunity to compare the cognitive abilities of all four great ape species," says Michael Tomasello, its co-director. "We will use both observational and experimental methods to investigate how apes solve ecological and social problems."

Sixty great apes - chimpanzees, bonobos, gorillas and orang-utans - will be delivered to the centre from zoos across Europe. Some have arrived already. Their new home consists of indoor and outdoor enclosures designed to imitate the apes' natural surroundings. There are no bars the apes are separated from visitors by moats or glass.

Research on intelligence, tool-using, numerical skills and social behaviour will start in June, once the animals have settled down and formed social groups.

Visitors will be able to watch the scientists working with the apes through panes of one-way glass in hidden observation corners. This level of openness is important to the project, says Josep Call, co-director of the centre. "Seeing apes solving problems in front of your eyes is very exciting - more so than seeing them on television."

Primate expert Jane Goodall, of the UKbased Jane Goodall Institute for Wildlife Research, Education and Conservation, has welcomed the centre. "Any new exhibit involving [highly endangered apes] that helps people to understand their true nature is to be applauded," she says.

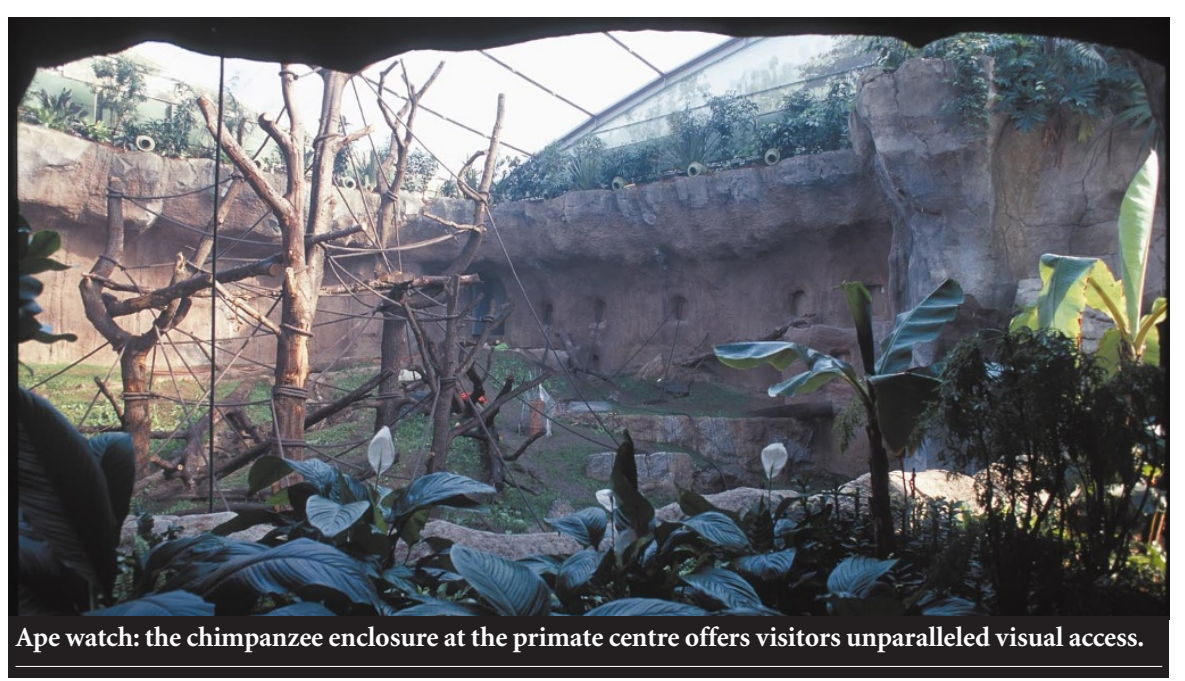

